\title{
The Roles of Source Characteristics in Building an Effective Digital Marketing Communication
}

\author{
Fatik Rahayu $^{1}$, Ayu Ekasari², Luki Adiati Pratomo ${ }^{3}$, \\ Annisa Yulistiari Banupa ${ }^{4}$, Khansa Fara Wijanarko ${ }^{5}$ \\ \{fatik.rahayu@trisakti.ac.id ${ }^{1}$, ayu.ekasari@trisakti.ac.id², luki.adiati@trisakti.ac.id ${ }^{3}$ \} \\ Faculty of Economic and Business, Universitas Trisakti, Jakarta, Indonesia ${ }^{1,2,3}$
}

\begin{abstract}
Studies have been conducted to analyze the role of source characteristics on purchase intention, yet results remain inconsistent. This present study was conducted to explore the intervening roles of some variables (attitude toward sources and attitude toward the brand) in mediating the relationship between source characteristics and purchase intention. Purposive sampling was administered to select respondents who had seen marketing communication in social media. SEM analysis was employed to determine the model of the relationship. The results showed that attitude toward sources and the brand intervened with the relationship between source characteristics and purchase intention. This study offers novel insights into the relationship model between source characteristics and purchase intention.
\end{abstract}

Keywords: Source Characteristics; Purchase Intention; Moderating Effect; Mediating Effect

\section{Introduction}

The rapid advancement of information technology brought conceptual and practical development in the marketing sector. There have been new conceptual marketing terms that reflects digitalization such as e-WOM, e-SERVQUAL, e-Value, e-Satisfaction and so on [1][3]. Online marketing or digital marketing has been a trend currently [4], [5]. This practice is accelerated during the Covid-19 pandemic, where the marketing communication strategy through digital media, or digital marketing, is considered the most appropriate method [6]. Digital marketing is a form of marketing communication that includes online marketing, mobile marketing, social media marketing, and e-WOM [7].

Conventional marketing communications through newspapers or magazines, brochures, printed catalogs are now considered less environmentally friendly [8]. In addition, digital marketing, also online purchase [6], [9] reduces air pollution from fuel consumption [6], [10]. As such, this study is expected to support green society by making digital marketing run effectively. During the Covid-19 pandemic, many people share product information through social media marketing [11]. They are referred to as endorsers, influencers, celebrities, vloggers, bloggers, and so forth [11], [12]. Marketers are recommended to select the best strategy for conveying messages, allowing marketing communications through digital media to run effectively [12]. Sources should be attractive, have characters that match the product 
being marketed, expertise related to the product, and honesty in conveying the message [12], [13] to generate a positive perception and positive consumer attitude towards the product or brand being promoted [14]. Furthermore, the positive attitude of consumers towards the product is expected to raise purchase intention [15].

Prior studies have identified an inconsistent relationship between source characteristics (source credibility) and consumer purchase intention. Gupta et al. (2015) succeeded in reviewing several studies on the influence of source credibility or characteristics on purchase intention from 1951 to 2013 , indicating the effect of source characteristics on purchase intention. However, other researchers did not find any significant influence of source characteristics on purchase intention [17]-[20]. Studies from 2014 to 2020 mainly developed the dimensions of source credibility or characteristics and added other variables known to affect purchase intention ([21], [22], [23], [24], [25], and [26]). Almost all of the hypotheses tested in these studies showed direct effects of two related variables. Only a small part of these studies examined possible moderating variables in the relationship between source characteristics and purchase intention. Thus, there is still a gap regarding the role of mediating variables in the relationship model between source characteristics and purchase intention.

\section{Literature Review}

\subsection{Source Characteristics}

Factors that affect the effectiveness of marketing communications include accuracy in selecting product sources [27], as validated by many researchers starting from 1951. Some researchers believed that reliable sources would affect consumer beliefs, opinions, attitudes, and behavior towards a product or company [12], [18], [19], [28]. Audiences' degree of trust in product sources is determined by three dimensions: likeability, expertise, and trustworthiness [27]. Other researchers analyzed several dimensions of source characteristics, and findings confirmed that likeability is interchangeable with attractiveness [14]. Most studies used three main dimensions: attractiveness, expertise, and trustworthiness ([22][22], [23], [24], [25], and [26]). Some researchers used different names or terms of these three main dimensions [25] and added other dimensions [29].

\subsection{Purchase Intention}

Purchase intention can be defined as the intention of consumers to buy a product [30]. Meanwhile, [31] stated that purchase intention was a tendency of a consumer to buy and take actions toward assessing an object. In addition, [31] also found purchase interest as the final stage of a complex purchase decision process. Similarly, [27] consider purchase intention as a response that arises after receiving a stimulus from the product that consumers see. This stimulus will then generate people's interest in trying out the product before growing the intention to buy the product.

\subsection{Previous Studies}

Studies on the effects of source characteristics on purchase intention show inconsistency in findings. One study found that attractiveness influenced purchase intention, while expertise did not affect Purchase Intention [32]. Other studies found that source credibility positively 
affected purchase behavior [33]. Others stated that attractiveness, expertise, and trustworthiness affected purchase intention [34]. Gupta et al. (2015) revealed that attractiveness and trustworthiness affected purchase intention, yet expertise did not. Of the four source characteristics (attractiveness, product relevancy, trustworthiness, and expertise), only attractiveness was not found to affect purchase intention [21]. [14] and [29] explained that attractiveness did not affect purchase intentions. This inconsistency becomes evident as [35] found trustworthiness did not affect purchase intentions, and [21] found only one dimension of trustworthiness (credibility) affected purchase intention. Inconsistent results show that the direct relationship model of source characteristics and purchase intention could not describe the actual condition. Therefore, the current model needs to be developed by involving other variables that might share mediating and moderating roles in the relationship between source characteristics and consumers' purchase intention.

\subsection{Model Development}

Based on the literature review, some variables might be mediating the relationship between source characteristics and purchase intention, including attitude toward sources and the brand. The model of the relationship examined in this study is illustrated as follows.

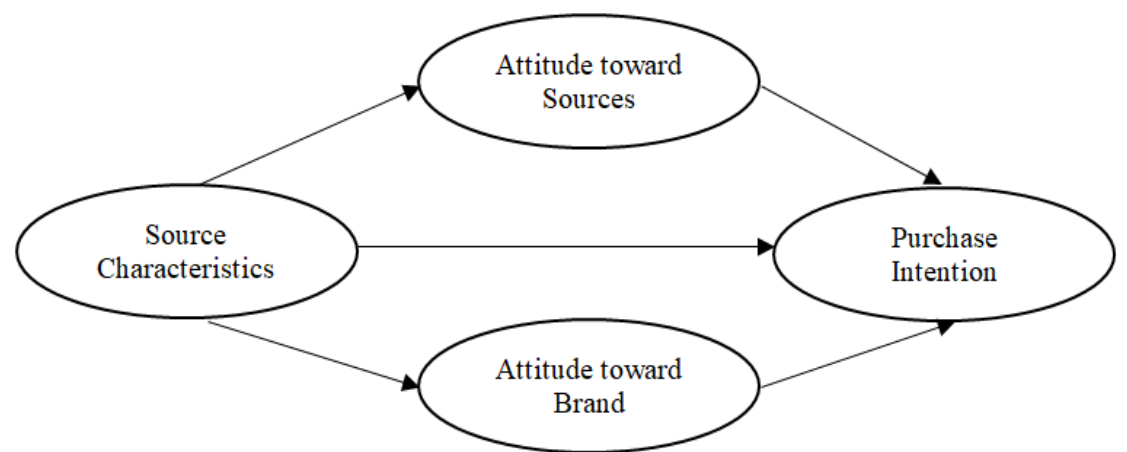

Fig. 1. The Consequences of Source Characteristics

\subsection{Hypotheses Formulation}

[25] showed that source characteristics did not directly affect purchase intention. However, source characteristics affected consumers' attitude to the brand and attitude to advertising, through which purchase intention could be affected. [25] did not examine the indirect effect of source characteristics on purchase intention through the attitude to the brand and advertising variables. Likewise, [14] only confirmed the direct influence of product source characteristics on attitude to the brand and the direct influence of attitude to the brand on purchase intention. Hence, it is assumed in this present study that attitude to source and attitude to the brand can be the mediating variables in the relationship between source characteristics and purchase intention.

H1: The influence of source characteristics on purchase intention is mediated by attitude toward sources

H2: The influence of source characteristics on purchase intention is mediated by attitude toward the brand 


\section{Methodology}

This study tested the relationship between source characteristics and consumers' purchase intention through attitude toward sources and brands. Respondents or units of analysis were individuals or consumers who often saw marketing communications conveyed by celebrities or non-celebrities on social media and those who followed specific social media influencers in the last six months. Filter questions were put in the questionnaire to allow only those who met the criteria to complete the questionnaires or ensure that the respondents meet these criteria. This study used 18 indicators.

The variables in this study were measured by modifying the instruments of previous researchers [13], [16], [21]-[24], [26], [29]. The instrument was tried out to 50 students (pilot study) to test the clarity of the indicators used in this study to ensure that readers understood the meaning of each statement. The accuracy of each indicator in measuring the variables was statistically measured using the Confirmatory Factor Analysis (CFA). Furthermore, internal consistency between indicators in measuring a variable was tested using the Cronbach Alpha correlation. The results of those tests showed that each variable in this study was valid and reliable.

Table 1. Results of Validity and Reliability Tests

\begin{tabular}{|c|c|c|c|}
\hline Variable/Dimension/Indicator & $\begin{array}{c}\text { Factor } \\
\text { Loading }\end{array}$ & $\begin{array}{l}\text { Cronbach's } \\
\text { Alpha }\end{array}$ & Conclusion \\
\hline Source Characteristics & & 0.874 & Reliable \\
\hline \multicolumn{4}{|l|}{ Attractiveness } \\
\hline Source has strong attractiveness & 0.690 & & Valid \\
\hline Source has a charming look & 0.608 & & Valid \\
\hline Source has a strong charisma & 0.705 & & Valid \\
\hline \multicolumn{4}{|l|}{ Trustworthiness } \\
\hline Source is honest & 0.782 & & Valid \\
\hline Source is sincere & 0.769 & & Valid \\
\hline Source is trustworthy & 0.694 & & Valid \\
\hline \multicolumn{4}{|l|}{ Expertise } \\
\hline Source has the skills/expertise in the brand being promoted & 0.637 & & Valid \\
\hline Source has experienced using the brand being promoted & 0.732 & & Valid \\
\hline $\begin{array}{l}\text { Source has broad knowledge regarding the brand being } \\
\text { promoted }\end{array}$ & 0.732 & & Valid \\
\hline Attitudes to Source & & 0.819 & Reliable \\
\hline Liking the source & 0.867 & & Valid \\
\hline Interested in the source & 0.907 & & Valid \\
\hline Trusting the source & 0.816 & & Valid \\
\hline Attitudes toward Brand & & 0.860 & Reliable \\
\hline Liking the brand being promoted & 0.890 & & Valid \\
\hline Interested in the brand being promoted & 0.889 & & Valid \\
\hline Trusting the brand being promoted & 0.877 & & Valid \\
\hline Purchase Intention & & 0.854 & Reliable \\
\hline Having the intention to buy the brand being promoted & 0.891 & & Valid \\
\hline Interested in buying the brand being promoted & 0.920 & & Valid \\
\hline $\begin{array}{l}\text { When planning to buy similar products, the brand being } \\
\text { promoted is put into consideration }\end{array}$ & 0.829 & & Valid \\
\hline
\end{tabular}

Structured Equation Model (SEM) using Amos was employed in data analysis. Before hypothesis testing, the model suitability test (Goodness of Fit / GOF) was first carried out. GOF test results showed that the proposed model was quite fit, as presented in Table 2. 
Table 2. Model Testing

\begin{tabular}{|c|c|c|c|}
\hline Measurement & Value & GOF Limit & Conclusion \\
\hline Chi Square & $\mathrm{p}$ value $=0.000$ & $\mathrm{P}$ value $>0.05$ & Poor GOF \\
\hline CMIN/DF & 4.436 & & Marginal GOF \\
\hline RMR & 0.066 & Small, close to 0 & GOF \\
\hline AIC & $\begin{array}{l}\text { Default Model: } 1042.001 \\
\text { Saturated Model: } 550.000 \\
\text { Independence } \\
\text { Model: } 3319.963\end{array}$ & $\begin{array}{l}\text { Default model value close } \\
\text { to the saturated model } \\
\text { value }\end{array}$ & GOF \\
\hline ECVI & $\begin{array}{l}\text { Default Model: } 5.236 \\
\text { Saturated Model: } 2.764 \\
\text { Independence Model: } 16.683\end{array}$ & $\begin{array}{l}\text { Default model value close } \\
\text { to the saturated model } \\
\text { value }\end{array}$ & GOF \\
\hline
\end{tabular}

As seen in Table 2, the small RMR value is close to 0; AIC and ECVI show that the model default value is close to the saturated model value. These values have met the requirements for the feasibility of a model. Thus, hypothesis testing could proceed [36].

\section{Results and Discussions}

The first hypothesis states that attitude to source variable mediated the relationship between endorsers' characteristics and purchase intention was tested. The model was divided into two to be compared. The first model only shows the direct effect of source characteristics on purchase intention. In the second model, attitude to sources is the mediating variable between source characteristics and purchase intention. The results of the first hypothesis testing are shown in Table 3.

Table 3. Results of the First Hypothesis Testing

\begin{tabular}{lccl}
\hline \multicolumn{1}{c}{ Model } & Estimate & p-value & Conclusion \\
\hline $\begin{array}{l}\text { Model 1: } \\
\text { Source characteristics influence the purchase intention }\end{array}$ & 0.703 & 0.000 & Positive influence \\
Model 2: & & & \\
Source characteristics influence the attitude to sources & 0.775 & 0.000 & Significant \\
Attitude to sources influence purchase intention & 0.364 & 0.02 & Significant \\
Source characteristics influence purchase intention & 0.432 & 0.000 & Significant yet weak \\
\hline
\end{tabular}

The first hypothesis was tested using two models, as shown in Table 3. As presented in the table, source characteristics influence purchase intention in model one ( $\mathrm{p}$-value $=0.000$ ) and remain significant in model two ( $p$-value $=0.000$, with a slight decrease in the influence strength from 0.703 to 0.432 ). Source characteristics also affect the attitude to sources (pvalue $=000$ ), and the attitude to endorsers also affects purchase intention ( $p$-value $=0.02$ ). Thus, hypothesis one that source characteristics influence purchase intention through attitude to sources was accepted. In model two, attitude to sources was partially mediated, indicating that source characteristics could directly affect purchase intention and indirectly influence sources through attitude.

As explained, attitude towards sources can mediate the influence of source characteristics on purchase intention. Therefore, managers can directly develop consumers' purchase intentions by selecting attractive, trustworthy sources with relevant expertise to the product being promoted. In addition to increasing consumers' purchase intentions directly, this strategy will also generate positive attitudes among consumers towards sources themselves, 
increasing consumers' purchase intentions. This study found the explanation on findings by Singh et al. (2018) that there was no direct influence of source characteristics on purchase intention. Likewise, [13] also found that source characteristics did not always share a direct influence on purchase intention.

Hypothesis two states that attitude to the brand mediates the relationship between source characteristics and purchase intention. It was tested by dividing the model into two for comparison. The first model only shows the direct influence of source characteristics on purchase intention. The second model includes attitude to the brand as a variable that mediates the influence of source characteristics on purchase intention. Table 4 shows the results of the second hypothesis testing as follows.

Table 4. Results of the Second Hypothesis Testing

\begin{tabular}{lccl}
\hline Model & Estimate & p-value & Conclusion \\
\hline Model 1: & & & \\
Source characteristics influence purchase intention & 0.703 & 0.000 & Positive influence \\
Model 2: & & & \\
Source characteristics influence attitude to the brand & 0.681 & 0.000 & Significant \\
Attitude to the brand influences purchase intention & 0.549 & 0.000 & Significant \\
Source characteristics influence purchase intention & 0.337 & 0.000 & Significant yet weak \\
\hline
\end{tabular}

Table 4 illustrates that source characteristics affect purchase intention in model one (pvalue $=0.000)$, and the influence remains significant in model two ( $p$-value $=0.000$, with weaker regression strength from 0.703 to 0.337 . There is an influence of source characteristics on attitude to the brand ( $\mathrm{p}$-value $=000$ ), and attitude to the brand also influences purchase intention ( $\mathrm{p}$-value $=0.000$ ). Thus, the second hypothesis was accepted. In this case, attitude to the brand has a partial mediating role, meaning that source characteristics can directly influence purchase intention and indirectly influence it through attitude to the brand.

It can be understood that the more attractive, the more trustworthy, and the more expert the sources, the more positive consumers' attitudes towards the brand will be. This condition, in turn, increases consumers' willingness to purchase the product from the brand. In this study, attitude towards the promoted brand shows a partial mediating role. It means that the source characteristics can either directly or indirectly influence consumers' intention to buy a product through consumer attitudes towards the brand of the product being promoted. Therefore, managers can improve consumers' purchase intentions by carefully selecting sources who are attractive, trustworthy, and have relevant expertise related to the product being promoted.

This study explained why Singh et al. (2018) did not find any direct influence of source characteristics on purchase intention. The findings complement [14] that confirmed only the influence of source characteristics on attitude to the brand and the attitude to the brand on purchase intention (without testing the indirect effect).

\section{Conclusions}

The data analysis confirmed that the two hypotheses proposed were accepted. Source characteristics influenced purchase intention through attitude towards sources and consumers' attitude towards the brand. The more attractive, trustworthy, and expert the sources, the more positive the consumers' attitude towards sources will be. Consumers' more positive attitudes towards sources will lead to a higher intention to buy the product or brand. 
This study proposes several managerial implications. First, managers can increase purchase intention by selecting more attractive, trustworthy product sources with a stronger expertise in promoting the product or brand. Product sources are considered more attractive when they have strong charisma and charming look-this will bring consumers' positive attitude towards sources. Second, managers should choose sources with a good track record (honest, trustworthy, and never involved in criminal or other crimes). Messages should be designed in such a way as to ensure that sources are sincere. The honesty and sincerity of sources will also increase the consumers' positive attitude towards the brand being promoted. Third, managers can also employ sources with sound expertise, knowledge, and experience related to the product or brand being promoted. Hence, consumers will grow positive attitudes to both the brand and sources.

\section{Limitations and Suggestions for Future Researchers}

This study only focuses on attitude (attitude to sources and brand) as mediating variables in the relationship between source characteristics and purchase intention. Other variables might also act as mediating variables. Future researchers are encouraged to overcome this limitation. Other variables such as e-WOM (Kudeshia and Kumar, 2017), created spokesperson (Sertoglu Et al., 2014), brand credibility, or consumer involvement (Wang \& Scheinbaum, 2018) are also assumed to add up to the understanding of sources' role in influencing consumers' purchase interest and purchase decisions.

\section{References}

[1] M. R. González-Rodríguez, R. Martínez-Torres, and S. Toral, "Post-visit and pre-visit tourist destination image through eWOM sentiment analysis and perceived helpfulness," Int. J. Contemp. Hosp. Manag., vol. 28, no. 11, pp. 2609-2627, 2016, doi: 10.1108/IJCHM-02-2015-0057.

[2] A. K. Abney, M. J. Pelletier, T. R. S. Ford, and A. B. Horky, “\#IHateYourBrand: adaptive service recovery strategies on Twitter," J. Serv. Mark., vol. 31, no. 3, pp. 281294, 2017, doi: 10.1108/JSM-02-2016-0079.

[3] M. I. Hussien and R. A. El Aziz, "Investigating e-banking service quality in one of Egypt's banks: A stakeholder analysis," TQM J., vol. 25, no. 5, pp. 557-576, 2013, doi: 10.1108/TQM-11-2012-0086.

[4] M. Hudák, E. Kianičková, and R. Madleňák, "The Importance of E-mail Marketing in E-commerce,” Procedia Eng., vol. 192, pp. 342-347, 2017, doi: 10.1016/j.proeng.2017.06.059.

[5] A. C. H. Lin, W. D. Fernandez, and S. Gregor, "Understanding web enjoyment experiences and informal learning: A study in a museum context," Decis. Support Syst., vol. 53, no. 4, pp. 846-858, 2012, doi: 10.1016/j.dss.2012.05.020.

[6] L. Nagel, "The influence of the COVID-19 pandemic on the digital transformation of work," Int. J. Sociol. Soc. Policy, vol. 40, no. 9-10, pp. 861-875, 2020, doi: 10.1108/IJSSP-07-2020-0323.

[7] P. Kotler and K. L. Keller, Marketing management. 2016.

[8] C. A. Rademaker and M. B. Royne, "Thinking green: How marketing managers select media for consumer acceptance," J. Bus. Strategy, vol. 39, no. 2, pp. 30-38, 2018, doi: 10.1108/JBS-05-2017-0070. 
[9] E. Pantano, C. V. Priporas, and G. Migliano, "Reshaping traditional marketing mix to include social media participation: Evidence from Italian firms," Eur. Bus. Rev., vol. 31, no. 2, pp. 162-178, 2019, doi: 10.1108/EBR-08-2017-0152.

[10] D. Zissis, E. Aktas, and M. Bourlakis, "Collaboration in urban distribution of online grocery orders,” Int. J. Logist. Manag., vol. 29, no. 4, pp. 1196-1214, 2018, doi: 10.1108/IJLM-11-2017-0303.

[11] K. Osei-Frimpong, G. Donkor, and N. Owusu-Frimpong, "The Impact of Celebrity Endorsement on Consumer Purchase Intention: An Emerging Market Perspective," $J$. Mark. Theory Pract., vol. 27, no. 1, pp. 103-121, 2019, doi: 10.1080/10696679.2018.1534070.

[12] K. P. Wiedmann and W. von Mettenheim, "Attractiveness, trustworthiness and expertise - social influencers' winning formula?," J. Prod. Brand Manag., no. January, 2020, doi: 10.1108/JPBM-06-2019-2442.

[13] S. W. Wang and A. C. Scheinbaum, "Enhancing brand credibility via celebrity endorsement trustworthiness trumps attractiveness and expertise," J. Advert. Res., pp. 16-32, 2018, doi: 10.2501/JAR-2017-042.

[14] N. M. Ha and N. H. Lam, "The Effects of Celebrity Endorsement on Customer's Attitude toward Brand and Purchase Intention," Int. J. Econ. Financ., vol. 9, no. 1, p. 64, 2016, doi: 10.5539/ijef.v9n1p64.

[15] Y. Chetioui, H. Benlafqih, and H. Lebdaoui, "How fashion influencers contribute to consumers' purchase intention,” J. Fash. Mark. Manag., vol. 24, no. 3, pp. 361-380, 2020, doi: 10.1108/JFMM-08-2019-0157.

[16] R. Gupta, N. Kishore, and D. Verma, "Celebrity Endorsements in Advertising: Impact on Consumers' Perception, Attitude and Purchase Intention," Aust. J. Bus. Manag. Res. New South Wales Res. Cent. Aust., vol. 05, no. 03, pp. 1-15, 2015.

[17] L. R. Kahle and P. M. Homer, "Physical Attractiveness of the Celebrity Endorser: A Social Adaptation Perspective," J. Consum. Res., vol. 11, no. 4, p. 954, 1985, doi: 10.1086/209029.

[18] K. Chan, yu Leung ng, and E. K. Luk, "Impact of celebrity endorsement in advertising on brand image among Chinese adolescents," Young Consum., vol. 14, no. 2, pp. 167179, 2013, doi: 10.1108/17473611311325564.

[19] R. R. Dholakia and B. Sternthal, "Highly Credible Sources: Persuasive Facilitators or Persuasive Liabilities?," J. Consum. Res., vol. 3, no. 4, p. 223, 1977, doi: $10.1086 / 208671$.

[20] R. N. Kanungo and S. Pang, "Effects of human models on perceived product quality," J. Appl. Psychol., vol. 57, no. 2, pp. 172-178, 1973, doi: 10.1037/h0037042.

[21] M. A. Adam and N. Hussain, "IMPACT OF CELEBRITY ENDORSEMENT ON CONSUMERS BUYING BEHAVIOR," Br. J. Mark. Stud., vol. 5, no. 3, pp. 79-121, 2017.

[22] C. Kudeshia and A. Kumar, "Social eWOM: does it affect the brand attitude and purchase intention of brands?," Manag. Res. Rev., vol. 40, no. 3, pp. 310-330, 2017, doi: 10.1108/MRR-07-2015-0161.

[23] K. Frimpong Osei, G. Donkor, and N. Owusu-Frimpong, "The Impact of Celebrity Endorsement on Consumer Purchase Intention: An Emerging Market Perspective," $J$. Mark. Theory Pract., vol. 27, no. 1, pp. 103-121, 2019, doi: 10.1080/10696679.2018.1534070.

[24] A. E. Sertoglu, O. Catli, and S. Korkmaz, "Examining the Effect of Endorser Credibility on the Consumers 'Buying Intentions : An Empirical Study in Turkey," Int. 
Rev. Manag. Mark., vol. 4, no. 1, pp. 66-77, 2014.

[25] R. P. Singh and N. Banerjee, "Exploring the influence of celebrity credibility on brand attitude, advertisement attitude and purchase intention," Glob. Bus. Rev., vol. 19, no. 6, pp. 1622-1639, 2018, doi: 10.1177/0972150918794974.

[26] J. Weismueller, P. Harrigan, S. Wang, and G. N. Soutar, "Influencer endorsements: How advertising disclosure and source credibility affect consumer purchase intention on social media," Australas. Mark. J., vol. 28, no. 4, pp. 160-170, 2020, doi: 10.1016/j.ausmj.2020.03.002.

[27] P. Kotler and K. L. Keller, Marketing Management, 14th ed. Prentice Hall, 2012.

[28] C. I. Hovland and W. Weiss, "The influence of source credibility on communication effectiveness," Public Opin. Q., vol. 15, no. 4, pp. 635-650, 1951, doi: $10.1086 / 266350$.

[29] M. M. Khan, "The Effect of Celebrity Endorsement on Consumer Purchase Intention Evidence From Q Mobile Linq Advertisement," Pakistan Bus. Rev., no. January, pp. 1065-1082, 2018.

[30] X. Bian and L. Moutinho, "The role of brand image, product involvement, and knowledge in explaining consumer purchase behaviour of counterfeits: Direct and indirect effects," Eur. J. Mark., vol. 45, no. 1, pp. 191-216, 2011, doi: 10.1108/03090561111095658.

[31] H. Assael, Consumer Behavior, 6th Editio. New York: Thomson Learning, 2001.

[32] B. D. Till and M. Busler, "The match-up hypothesis : Physical attractiveness , expertise , and the ...," J. Advert., vol. 29, no. 3, pp. 1-13, 2000.

[33] R. E. Goldsmith, B. A. Lafferty, and S. J. Newell, "The impact of corporate credibility and celebrity credibility on consumer reaction to advertisements and brands," $J$. Advert., vol. 29, no. 3, pp. 43-54, 2000, doi: 10.1080/00913367.2000.10673616.

[34] C. Pornpitakpan, "The Effect of Celebrity Endorsers' Perceived Credibility on Product Purchase Intention," J. Int. Consum. Mark., vol. 16, no. 2, pp. 55-72, 2003, doi: 10.1300/J046v16n02.

[35] Hakimi, B. Yousef, A. Abed, and M. N. Zaeim, "Investigate the Impact of Celebrity Endorsement on Brand Image," Eur. J. Sci. Res., vol. 58, pp. 116-132, 2011.

[36] S. H. Wijayanto, SEM dengan Lisrel 8.8: Konsep dan Tutorial, Yogyakarta: Graha Ilmu. 2008. 